\title{
Akademisyenlerin Algıladıkları Mobbing ve Mesleki Tükenmişlik Düzeylerinin Çeşitli Değişkenlere Göre İncelenmesi
}

\section{Dr. Öğr. Üyesi Ayfer Öztürk ${ }^{1 *}$}

Geliş tarihi: 27.06 .2019

Kabul tarihi: 17.09.2019

\section{Atıf bilgisi:}

IBAD Sosyal Bilimler Dergisi

Sayı: Özel Sayı Sayfa: $314-325$

Yıl: 2019

This article was checked by iThenticate. Similarity Index $28 \%$.

1 Bartın Üniversitesi, Sağllk Bilimleri Fakültesi, Psikiyatri Hemșireliği Anabilim Dali,

Türkiye,
ÖZ

$\mathrm{Bu}$ araștırmada akademisyenlerin algıladıkları mobbing ile mesleki tükenmişlik düzeylerinin çeşitli değişkenlere göre incelenmesi amaçlandı. Araştırma bir devlet üniversitesinde görev yapan araştırmaya katılmaya gönüllü 90 akademisyen ile gerçekleştirildi. Araştırma verileri 'Kişisel Bilgi Formu', 'Akademisyenlere Yönelik Mobbing Ölçeği (AYMÖ)', ve 'Maslach Tükenmişlik Ölçeği (MTÖ)' kullanılarak e-posta yolu ve yüz yüze olarak toplandı. Akademisyenlerin \%57'si kadın, \%54,4'ü evli, \%45,5'i 30-39 yaş aralığındaydı. \%54,4'ü daha önce mobbinge maruz kaldıklarını bildirdi. Mobbing uygulayanların çoğunluğunun $(\% 68,8)$ yöneticilik görevleri olduğu, bu yöneticilik görevlerinin ise daha çok Bölüm Başkan1/müdür/dekan olduğu belirlendi. Algılanan mobbing ve tükenmişlik düzeyinin yaş, cinsiyet, medeni durum, ve akademik ünvan değişkeni açısından farklılaşmadığı saptandı. Ancak akademisyenlerin kıdem yılına göre algıladıkları moobing düzeyleri $(p=0,017)$ ile tükenmişlik $(p=0,001)$ düzeyleri arasında istatistiksel olarak anlamlı fark saptand $1(p<0,05)$. Akademisyenlerin \%55,6's uygulanan mobbing karșısında sessiz kaldıklarını, \%24,4'ü iși bırakmak istediğini belirtti. Akademisyenlerin algıladıkları mobbing puan ortalaması 56,76, duygusal tükenme altboyutu puan ortlaması 17,36 ve duyarsızlaşma altboyutu puan ortlaması ise 12,37 olarak saptand. Araştırma sonucunda, akademisyenlerin algıladıkları mobbing ve tükenmişlik düzeylerinin ortalamanın üstünde olduğu, kıdem yılının ise bu düzeyleri etkilediği görüldü. Çalışmanın daha geniş örneklem gruplarıyla ve farklı üniversitelerde uygulanması önerilmektedir.

Anahtar Kelimeler: Akademisyen, mobbing, tükenmişlik, ölçek, Sosyodemografik değişkenler

* Sorumlu yazar 


\section{A Study of the Professional Burnout Levels and Mobbing Perceived by Academics to Various Variables}

Assist. Prof. Dr. Ayfer Öztürk ${ }^{1^{*}}$

First received: 27.06 .2019

Accepted: 17.09.2019

\section{Citation:}

IBAD Journal of Social Sciences

Issue: Special Issue Pages: 314-325

Year: 2019

This article was checked by iThenticate. Similarity Index $28 \%$.

1 Bartın Universitiy, Faculty of Health Sciencesi Nursing Department, Turkey, ayferozturk.83@yahoo.com

ORCID ID 0000-0002-3092-0671

* Corresponding Author

\begin{abstract}
In this study, it was aimed to investigate the perceived mobbing and occupational burnout levels of academicians according to various variables. The study was carried out with 90 academicians who volunteered to participate in the research at a public university. The data were collected via e-mail and face to face by using 'Personal Information Form', 'Mobbing Scale for Academicians and Maslach Burnout Scale MT (MBI). 57\% of the academicians were women, $54.4 \%$ were married and $45.5 \%$ were in the $30-39$ age range. $54.4 \%$ of them reported that they had been exposed to mobbing before. It was determined that the majority $(68.8 \%)$ of the mobbing practitioners had managerial duties and these managerial duties were mostly Head of Department / Director / Dean. It was found that perceived mobbing and burnout levels did not differ in terms of age, gender, marital status, and academic variable. However, there was a statistically significant difference between the levels of mobbing $(\mathrm{p}=0.017)$ and burnout $(\mathrm{p}=0.001)$ perceived by academicians according to seniority year $(p<0.05)$. $55.6 \%$ of academics stated that they were silent in the face of mobbing and $24.4 \%$ said they wanted to quit. The average score of mobbing perceived by the academicians was 56.76 , the mean score of emotional exhaustion subscale was 17.36 and the mean score of depersonalization subscale was 12.37. As a result of the study, it was seen that the perceived mobbing and burnout levels of the academicians were above the average and the seniority year affected these levels. It is recommended that the study needs to be conducted with larger sample groups and different universities.
\end{abstract}

Keywords: Academician, mobbing, burnout, scale, sociodemographic variable 


\section{GİRIŞ}

Eylem olarak uzun yıllardır var olmasına rağmen isimlendirilmesi yeni olan mobbing kavramı; iş yaşamına yeni girmiş bir kavramdır. Psikolojik yıldırma, duygusal taciz, zorbalık gibi farklı kelimelerle ifade edilmeye çalışılan bu kavram, öncelikle özel sektörde ele alınmış zamanla kamu sektöründe de dikkat çekmeye başlamıştır (Güven, Kaplan ve Acungil, 2018).

Mağduru yalıtan ve ümitsizlik nedeniyle intihara kadar götürebilen mobbing süreci zaman içerisinde farklı şekillerde tanımlanmıştır. İş yerinde mobbing kavramı geniş şekli ile 1980'li yılların sonunda İsveç'te yaşayan Psikolog Dr. Heinz Leymann tarafından tanımlanmaktadır. Leymann'a (1990) göre mobbing; bir ya da birkaç bireyin genellikle tek bir bireye karşı sistematik bir şekilde uyguladıkları düşmanca ve ahlaki olmayan davranışları içermektedir (Leyman,1990). Bu durum bireyi savunmasızlığa ve çaresizliğe itmekte; devam eden taciz davranışlarıyla da bireyin bu durumdan kurtulması engellenmektedir. Söz konusu davranışlar sıklıkla tekrarlanmakta (en az haftada bir kez) ve belirli bir süreçte (en az altı ay) devam etmektedir (Laleoğlu ve Özmete, 2013).

Mobbing sürecinde; fizyolojik yatkınlıklar, deneyimler, kişilik özellikleri, sosyal destek kaynakları gibi pek çok faktör etkili olmaktadır. Kişilik özellikleri, bireylerin mobbinge karşı direncini etkilemektedir (Eroğlu, 1996, akt: Laleoğlu ve Özmete, 2013). Yeni fikirler üretebilen, farklı bakış açılarıyla dünyayı yorumlayabilen bireyler mobbing mağduru olabilmektedirler. Eğitim, dış görünüş, entelektüel birikim açısından parlak çalışanlar, rekabetçi ve bencil bireyler için kolay hedef haline gelebilmektedirler (Kirel, 2007).

Mobbing hem örgütsel hem de kişisel sonuçlar doğuran bir olgudur. Gerek örgütlerde gerekse bireylerde ciddi sorunlara yol açmaktadır (Güven vd., 2018). Bu süreçten en çok etkilenen ise hiç kuşkusuz mobbinge uğrayan kişidir. Mobbinge uğrayan kişiler zamanla mahcubiyet, damgalanma, kaygılanma, korkaklık, düşmanca davranışlar, aşırı duyarlı olma, işe yabancılaşma, çalışma arkadaşlarıyla uyuşamama ve üretkenliğin azalması, çaresizlik hissi, kendini suçlu görme, çalışma arkadaşlarına ve yöneticilerine karşı güven duymama, işten ayrılmaya teşebbüs, sosyal olarak kendini geri çekme, sosyal fobi, örgütsel bağl1lı̆̆ın azalması, işe gelmeme ve işten ayrılmanın artması, motivasyon ve üretimde düşme vb. sorunlar yaşamaya başlarlar (Deniz, 2012). Mobbingin mağdur açısından en önemli sonuçları, genelde psikosomatik bozukluklar ve sağlık sorunlarıdır (Matthiesen ve Einarsen, 2010). Bunun yanında Mobbingin ekonomik sonuçlarına bakıldığında, doktorlara, ilaçlara, hastanelere ödenen paralar göze çarpar. Mağdur işten ayrılmak zorunda kalırsa ya da işten çıkarılırsa bunun neticesinde düzenli geliri yok olur (Tinaz, 2006).

Akademisyen; üniversite ve benzeri yükseköğrenim kurumlarında öğretimi gerçekleştiren, araştırma yapan ve özgün araştırmalarıyla alanına katkıda bulunan kişilere verilen genel mesleki unvandır. Üniversitelerde ve araştırma kurumlarında görev yapan öğretim yardımcıları olan çevirmenler, uzmanlar, öğretim planlamacıları, araştırma görevlileri, okutmanlar ve öğretim görevlileri ile öğretim üyeleri olan yardımcı doçentler, doçentler ve profesörler farklı derecelerden akademisyenlerdir (YÖK, 1981, 2007).

Akademik kariyer oldukça uzun ve yorucu bir süreçtir. Bu süreçte bazı akademisyenlerin psikolojik tacize maruz kalma riski vardır (Öztürk ve Şahbudak, 2017). Bununla birlikte üniversitelerde hem akademisyenler hem de diğer çalışanlar çeşitli düzey ve şekillerde zaman zaman işyerinde psikolojik tacize maruz kalabilmektedir. Üniversitelerde işyerinde psikolojik tacizin düzeyi ve şekli akademik ve idari personel açısından farklılık göstermektedir (Öztürk ve Şahbudak, 2017). Üniversite düzeyinde ele alındığında, düşünceyi ifade etmenin en özgür kullanılacağı yer olan üniversitelerin mobbingle anılması ciddi bir tezat oluşturmaktadır (Güven vd., 2018). Hiçbir üniversite mobbing konusuyla anılmak istememektedir. Ancak insan unsurunun olduğu her örgütte azda olsa mobbingle karşılaşılması kaçınılmazdır. Türkiye'de özel ve kamu üniversitelerinde çalışan akademisyenlerin mobbing algılarını tespit etmeye yönelik gerçekleştirilen birçok araştırmada maalesef özel ya da kamusal olmasına bakılmaksızın mobbing sorununun varlığına yönelik işaretlere rastlandığı görülmektedir (Güven vd., 2018; Softa vd., 2016; Çivilidağ 2011; Çögenli ve Asunakutlu, 2016; 
Çögenli, 2010; Şenerkal ve Çorbacıŏglu, 2015; Türeli ve Dolmacı, 2014; Kayac1, 2014; Karahan, 2016; Şahbudak ve Öztürk 2015; Öztürk ve Şahbudak, 2017).

İşyerinde mobbing, diğer kurbanlar gibi akademisyenlerin fiziksel ve psikolojik sağlığını tehdit etmektedir. Baş ağrısı, ağır depresyon, özgüven eksikliği, iştahsızlık, baş ağrısı, paranoya, konsantrasyon eksikliği, mesleki tükenmişlik, alkol, sigara ve ilaç kullanımlarında artış, saldırganlık, karamsarlık gibi belirtiler mağdur akademisyenlerin yakındığı sağlık sorunları arasındadır (Karatuna ve Gök, 2012).

Kişilerin işlerinde yaşadıkları ilişkilerin zorlaşması ve bu sonuca bağlı olarak bir şeylerin ters gittiği yolundaki inançların artmasıyla gelişen süreç kişileri modern çağın önemli bir problemi tükenmişlik (burnout) ile karşı karşıya bırakmaktadır.

Tükenme, son yıllarda üzerinde önemle durulan ve hemen her çeşit iş yerinde çalışan tüm insanlarda görülebilen bir sorun olmuştur. İşinde doyumsuzluk yaşayan birey, olumsuz duygulara yönelir. $\mathrm{Bu}$ olumsuz duygular ise onun bedensel, ruhsal ve sosyal sağlığını bozar. Bunun sonunda bireyde işten uzaklaşma, işi terk etme sık s1k iş değiştirme gibi iş doyumsuzluğu ve tükenmişlik belirtileri görülebilir (Karadağ, 2002 Akt: Serinkan ve Bardakçı, 2009). Tükenmişlik (burnout) çoğunlukla bir semptom örüntüsü olarak tanımlanmıştır. Tükenmişlik yaşayan kişide genel olarak, mesleki doyumsuzluk ve yorgunluk görülür. İșe gitmeme isteği, tahammülsüzlük, kendinden şüphelenme ve kendi imajına uygun olmayan davranışlar görülür (Çam, 1993).

Literatürde en çok atıfta bulunulan ve en yaygın şekilde kabul gören tükenmişlik tanımını Christina Maslach yapmıştır. Maslach'ın yaygın kabul gören tükenmişlik tanımı şöyledir; “ bireyin işi dolayısı ile sürekli diğer insanlarla yüz yüze çalışmak durumunda kalması ve bu esnada yoğun duygusal taleplerle karşılaşması sonucu yaşadığı duygusal tükenme, duyarsızlaşma ve düşük kişisel başarı hissi”" (Maslach vd., 2001).

Tükenmişliğin genellikle duygusal tükenme, duyarsızlaşma ve kişisel başarıda düşüklük hissi olmak üzere üç boyutundan bahsedilmektedir (Maslach, 2003, Maslach ve Jackson, 1981; Maslach vd., 2001).

Bireyde tükenme durumunda ortaya çıkabilecek bir takım belirtiler bulunmaktadır. Bunlar; yorgunluk ve bitkinlik hissi, enerji kaybı, uyku bozuklukları, gastrointestinal bozukluklar ve kilo kaybı, solunum güçlüğ̈̈, psikosomatik hastalıklar, koroner kalp rahatsızlığı, psikolojik belirtiler; duygusal bitkinlik, kronik sinirlilik hali, bilişsel becerilerde güçlükler yaşama, anksiyete, huzursuzluk, benlik saygısında düşme, ümitsizlik, davranışsal belirtiler; hatalar yapma, bazı işleri erteleme, işe geç gelme, izinsiz olarak yada hastalık nedeni ile işe gelmeme, hizmetin niteliğinde bozulma, kaza ve yaralanmalarda artış, meslektaşlara ve hizmet verilen kişilere mesafeli davranışlar, alaycı davranışlar şeklinde sıralanabilir (Varhama ve Björkqvist, 2004).

Yapılan araştırmalarda, mobbing mağduru kişilerin kendilerini kimliksiz hissetmeye başladığı, psikolojik ve fizyolojik birçok hastalığın ortaya çıktığı ve stres, özgüven eksikliği yaşadıkları ortaya çıkmıştır. Mobbing mağdurlarıyla yapılan görüşmelerde mobbing mağdurlarının psikolojik olarak endişe, panik ataklar, öfke, güven eksikliği, sinirlilik belirtileri, kayıtsızlık, konsantrasyon bozukluğu ve sosyal fobiler olduğu, fiziksel belirtiler olarak terleme, titreme, uykusuzluk olduğu sonucuna varılmıştır (Cooper vd., 2004). Bütün bu bulgular, işyerinde mobbingin tükenmişlik sendromu ile bağlantılı bir yapı içerdiğini düşündürmektedir. $\mathrm{Bu}$ şekilde, çeşitli yıldırma ve duygusal şiddet eylemlerinin çalışanların dayanma güçlerini, verimliliklerini önce düşürüp sonra da tükenmişlik yaşatarak onları işten uzaklaştırmaya ve ayrılmaya zorlamakta olduğu belirtilmektedir. Bu bakımdan, çalışma yaşamının değişik evrelerinde ortaya çıkabilen, bireyin enerji kaynaklarının stres yapıcı koşullar altında azalmasını ifade eden tükenmişlik kavramını, mobbing olgusunun bağlamında ele alma ihtiyacı doğmaktadır (Sart vd., 2018).

Üniversitelerde mobbing konusu pek çok kez ele alınmış olmasına rağmen, akademik örgütlerde mobbing ile tükenmişlik kavramlarını beraber ele alan araştırma oldukça sınırlıdır (Sart vd., 2018). Dolayısıyla araştırmanın literatüre katkıda bulunacağı düşünülmektedir.

\section{Araştırma Soruları}


1- Akademisyenlerin algıladıkları mobbing ve tükenmişlik düzeyleri üzerinde yaş, cinsiyet medeni durum, kıdem yılı ve unvan gibi çeşitli değişkenlerin etkisi var mıdır?

2- Akademisyenlerin mobbinge maruz kalmalarının sebepleri ve verdikleri tepkiler nelerdir?

3- Akademisyenlerin algıladıkları mobbing ve tükenmişlik düzeyleri nasıldır?

\section{GEREÇ VE YÖNTEM}

Çalışmanın bu bölümünde araştırmanın örneklemi, veri toplanma yöntemi ve araçları, araştırma soruları ve sınırlılıklarına ait bilgilere yer verilmiştir.

\section{Araştırmanın Evren ve Örneklemi}

Araştırmanın evrenini Bartın Üniversitesi’nde görev yapan öğretim elemanları oluşturmaktadır. Bartın Üniversitesinde görev yapan 580 akademik personel bulunmaktadır. Araştırma için örneklem seçimine gidilmeyip bütün akademik personele ulaşılması hedeflenmiş olup araştırmaya katılmaya gönüllü 90 akademisyen ile araştırma tamamland.

\section{Verilerin Toplanması}

Araştırma verileri Mart 2019-Mayıs 2019 tarihleri arasında E-posta ile elektronik ortam üzerinden toplandı. Veri toplama araçları (ölçek ve anket formları) bir link yardımı ile akademisyenlerin e-posta adreslerine gönderildi ve araştırmanın amacı ve araştıramaya katılımın gönüllük esasına dayandığı mail içeriğinde belirtildi. Veriler link yardımı ile üniversitenin UBYS sistemi üzerinden toplandığı için katılımcıların kimlik bilgileri gizli kaldı. Veri toplama araçlarının doldurulması yaklaşık 10-15 dakika sürdü.

\section{Veri Toplama Araçları}

Kişisel Bilgi Formu: Araştırmacı tarafindan literatür bilgisinden yararlanarak hazırlanan formda katılımcıların tanımlayıcı bilgilerini (yaş, cinsiyet, medeni durum, unvan, kıdem yılı, çalıştığı fakülte), mobbing maruziyet durumuna yönelik soruları içeren toplam 16 soru bulunmaktadır.

Akademisyenlere Yönelik Mobbing Ölçeği (AYMÖ): Ölçek akademisyenlerin maruz kaldıkları mobbing davranışlarını belirlemek için Çögenli ve Asunakutlu (2014) tarafından geliştirilmiştir. 5 alt boyut ve 29 maddeden oluşan ölçek 5'li likert tipi (Hiçbir zaman, Nadiren, Bazen, Genellikle, Her zaman) bir ölçektir. Yapılan geçerlik ve güvenirlik çalışmaları sonucunda ölçek 5 altboyut altında toplam 23 maddeden oluşmaktadır. Ölçekte, Kendini Gösterebilmeye ve İletişime Yönelik Saldırılar ile ilgili 6, Sosyal İlişkilere Yönelik Saldırılar ile ilgili 4, İtibara Yönelik Saldırılar ile ilgili 3, Mesleki Duruma Yönelik Saldırılar ile ilgili 7 ve Kişinin Psikolojik Sağlığına Yönelik Saldırılar ile ilgili 3 soru yer almaktadır. Ölçeğin puanları 23 ile 115 arasında değişmektedir. Akademisyenlere Yönelik Mobbing Ölçeğinin (AYMÖ) güvenirliği Cronbach Alpha katsayısı ile belirlenmiştir. Ölçeğin tamamına ilişkin güvenilirliği (Cronbach's Alpha) $\alpha=0,970$ olarak bulunmuştur. Ölçeğin alt boyutlarını oluşturan güvenirlik katsayıları: 1. Kendini Gösterebilmeye ve İletişime Yönelik Saldırılar $(\alpha=0,899), 2$. Sosyal İlişkilere Yönelik Saldırılar $(\alpha=0,917), 3$. İtibara Yönelik Saldırılar $(\alpha=0,821), 4$. Mesleki Duruma Yönelik Saldırılar $(\alpha=0,911)$ ve 5. Kişinin Psikolojik Sağlığına Yönelik Saldırılar $(\alpha=0,740)$ şeklinde bulunmuştur (Çögenli ve Asunakutlu, 2014). Bu çalışmada ölçeğin Cronbach's Alpha değeri 0,959 olarak hesaplanmıştır.

Maslach Tükenmişlik Ölçeği (MTÖ): Akademik personelin tükenmişlik düzeyini ölçmek için "Maslach Tükenmişlik Ölçeği” kullanılmıştır. Bu ölçek, Maslach ve Jackson tarafından 1981 yılında geliştirilmiş ve Ergin tarafından da 1992 yılında ölçeğin Türkçe'ye uyarlaması yapılmıştır. (Maslach ve Jackson, 1981, Ergin 1992). Maslach Tükenmişlik Ölçeği, "duygusal tükenme”, duyarsızlaşma" ve kişisel başarılarım” boyutlarını kapsayan 22 sorudan oluşmaktadır. 22 sorunun 9'u duygusal tükenme, 5'i duyarsızlaşma ve 8'i kişisel başarım boyutlarını temsil etmekte ve sorular 5 dereceli likert şeklinde, şiddet derecelerine göre 0: Hiçbir zaman, 1: Çok nadir, 2: Bazen, 3: Çoğu zaman ve 4: Her zaman şeklinde cevaplanmaktadır (Ergin 1992).

Maslach Tükenmişlik Ölçeği'nin, duygusal tükenme kısmını temsil eden; 1, 2, 3, 6, 8, 13, 14, 16 ve 20 numaralı soruları ve duyarsızlaşma kısmını temsil eden 5, 10, 11, 15, ve 22 numaralı soruları, olumsuz 
ifadelerden oluşurken, ölçeğin üçüncü kısmı olan kişisel başarım ise 4, 7, 9, 12, 17, 18, 19 ve 21 numaralı sorularla temsil edilmekte ve olumlu ifadelerden meydana gelmektedir. Tükenmişlik düzeyi tek bir puanla değil alt ölçeklerden alınan her bir puanın ayrı ayrı değerlendirilmesi şeklinde hesaplanır. Ölçekteki alt boyutların hepsi $0,1,2,3$ ve 4 puan şeklinde hesaplanır, duygusal tükenme ve duyarsızlaşma puanlarının yüksek, kişisel başarım puanının düşük olması, yüksek derecede tükenmişliği gösterir. Ölçekte yer alan ifadelere 5'li Likert formatında yanıt istenmiştir, buna göre 4= Her zaman; 0= Hiçbir zaman'1 ifade etmektedir. "Ölçeğin Cronbach alfa değeri Ergin (1992)'in çalışmasında 0.83 , Yürür ve Keser $\left(2010=\right.$ in çalışmasında $0.88^{\prime}$ dir. Bu çalışmada toplam ölçek Cronbach's Alpha değeri 0,803 olarak hesaplanmıştır.

\section{Etik Prosedür}

Araştırmanın uygulanabilmesi için Bartın Üniversitesi Etik Kurulu'ndan Etik Kurul İzni (2019-024) alınmıştır. Anket ve ölçek formlarının uygulanmasında gönüllülük esas alınarak, çalışma hakkında katılımcılara bilgi verilmiş ve onayları alınmıştır. Bartın Üniversitesi Kalite Koordinatörlüğü Ölçme ve Değerlendirme biriminden; araştırmanın amaç ve kapsamını içeren bilgi formu, araştırmada kullanılacak ölçek formları ve etik kurul formu sunularak izin alınmıştır.

\section{Verilerin Analizi}

Verilerin normal dağılıma uygunluğu Shaphiro Wilk testi ile test edilmiş, Normal dağılıma sahip özelliklerin 2 bağımsız grupta karşılaştırılmasında Student t testi, normal dağılmayan özelliklerin 2 bağımsız grupta karşılaştırılmasında Mann Whitney u testi kullanılmıştır. Ayrıca sayısal verilerin 2 den fazla bağımsız grupta karşılaştırılmasında normal dağılım gösteren özellikler için Tek yönlü varyans analizi (ANOVA) ve LSD çoklu karşılaştırma testleri, normal dağılmayan özellikler için ise Kruskal Wallis testi ve All pairwise çoklu karşılaştırma testi kullanılmıştır. Tanımlayıcı istatistik olarak sayısal değiş̧kenler için ortalama \pm standart sapma, kategorik değişkenler için ise sayı ve \% değerleri verilmiştir. İstatistiksel analizler için SPSS paket programı kullanılmış ve $p<0.05$ istatistiksel olarak anlamlı kabul edilmiştir.

\section{BULGULAR}

\section{Akademisyenlerin Tanımlayıcı Özellikleri ve Mobbinge Maruz Kalma Durumları}

Akademisyenlerin \%57'si kadın, \%54,4'ü evli, \%45,5'i 30-39 yaş aralığındadır. Akademisyenlerin \%8.82'i Prof. Dr., \%7,7'si Doç. Dr., \%28’i Dr. Öğr. Üyesi，\%33.3'ü Öğretim Görevlisi, \%21,1’i Arş. Görevlisidir. Akademisyenlerin \%54,4’ü daha önce mobbinge maruz kaldıklarını ve mobbing uygulayıcılarının ise \%33,3'nün erkek olduğunu belirtmişlerdir.

Mobbing uygulayanların çoğunluğunun $(\% 68,8)$ yöneticilik görevleri olduğu, bu yöneticilik görevlerinin ise daha çok Bölüm Başkanı/müdür/dekan olduğu bulunmuştur (Tablo 1).

Tablo 1. Akademisyenlerin ve mobbing uygulayıcıların tanımlayıcı özelliklerine göre dağılımları $(\mathrm{n}=90)$

\begin{tabular}{|c|c|c|c|c|c|c|c|}
\hline & & f & $\%$ & & & f & $\%$ \\
\hline \multirow[b]{2}{*}{ Cinsiyet } & \multirow{2}{*}{$\begin{array}{l}\text { Kadın } \\
\text { Erkek }\end{array}$} & 52 & 57,0 & \multirow{4}{*}{ Kidem y1lı } & \multirow{4}{*}{$\begin{array}{l}0-5 \text { y1l } \\
6-10 \text { y1l } \\
11-15 \text { y1l } \\
16-20 \text { yil } \\
21 \text { y1l ve daha fazla }\end{array}$} & 28 & 31,1 \\
\hline & & 38 & 42,7 & & & 24 & 27,6 \\
\hline \multirow{2}{*}{$\begin{array}{l}\text { Medeni } \\
\text { durum }\end{array}$} & \multirow{2}{*}{$\begin{array}{l}\text { Evli } \\
\text { Bekar }\end{array}$} & 49 & 54,4 & & & 15 & 17,2 \\
\hline & & 41 & 45,5 & & & $\begin{array}{l}12 \\
11\end{array}$ & $\begin{array}{l}13,8 \\
12,6\end{array}$ \\
\hline \multirow{5}{*}{ Ünvan } & \multirow{5}{*}{$\begin{array}{l}\text { Arş. Gör. } \\
\text { Öğr.Gör./Okutman/Uzm } \\
\text { Dr. Öğr. Üyesi } \\
\text { Doç. Dr. } \\
\text { Prof. Dr. }\end{array}$} & 19 & 21,1 & \multirow[t]{5}{*}{ Yaş } & 29 ve alt1 & 16 & 17,8 \\
\hline & & 30 & 33,3 & & $30-39$ & 44 & 48,9 \\
\hline & & 26 & 28,9 & & $40-49$ & 17 & 18,9 \\
\hline & & 7 & 7,8 & & $50-59$ & 11 & 12,2 \\
\hline & & 8 & 8,9 & & 60 yaş ve üzeri & 2 & 2,2 \\
\hline \multirow{3}{*}{$\begin{array}{l}\text { Mobbinge } \\
\text { maruziyet }\end{array}$} & \multirow{3}{*}{$\begin{array}{l}\text { Evet } \\
\text { Hayır } \\
\text { Kismen }\end{array}$} & 49 & 54,4 & \multirow{3}{*}{$\begin{array}{l}\text { Mobbin } \\
\text { uygulayan } \\
\text { Cinsiyeti }\end{array}$} & \multirow{3}{*}{\begin{tabular}{|l|} 
Kadın \\
Erkek \\
İkisi de
\end{tabular}} & 26 & 28,8 \\
\hline & & 20 & 22,2 & & & 30 & 33,3 \\
\hline & & 21 & 23,3 & & & 34 & 37,7 \\
\hline \multirow{2}{*}{$\begin{array}{l}\text { Mobbing } \\
\text { uygulayanın }\end{array}$} & \multirow{2}{*}{$\begin{array}{l}\text { Var } \\
\text { Danışman* }\end{array}$} & 62 & 68,8 & \multirow{2}{*}{$\begin{array}{l}\text { Mobbing e } \\
\text { maruz }\end{array}$} & \multirow{2}{*}{$\begin{array}{l}\text { Arş. Gör.* } \\
\text { Öğr.Gör.* }\end{array}$} & 34 & 37,8 \\
\hline & & 13 & 14,4 & & & 27 & 30 \\
\hline
\end{tabular}




\begin{tabular}{|c|c|c|c|c|c|c|c|}
\hline \multirow{8}{*}{$\begin{array}{l}\text { yöneticilik } \\
\text { görevi } \\
\text { olma } \\
\text { durumu }\end{array}$} & \multirow{8}{*}{$\begin{array}{l}\text { Anabilimdalı Başkanı* } \\
\text { Bölüm Başkan Yrd.* } \\
\text { Bölüm Başkanı* } \\
\text { Dekan/müdür Yard. }{ }^{*} \\
\text { Dekan/Müdür* } \\
\text { Rektör Yardımcısı* } \\
\text { Rektör* } \\
\text { Yok }\end{array}$} & 18 & 21,1 & \multirow{3}{*}{$\begin{array}{l}\text { kalınan } \\
\text { ünvan }\end{array}$} & \multirow{3}{*}{$\begin{array}{l}\text { Dr. Öğr. Üyesi* } \\
\text { Doç. Dr. }^{*} \\
\text { Prof. Dr. }^{*}\end{array}$} & 21 & 23,3 \\
\hline & & \multirow{7}{*}{$\begin{array}{r}12 \\
26 \\
21 \\
26 \\
5 \\
11 \\
28\end{array}$} & \multirow{7}{*}{$\begin{array}{r}13,3 \\
28,9 \\
23,3 \\
28,9 \\
5,6 \\
12,2 \\
31,1\end{array}$} & & & 5 & 5,6 \\
\hline & & & & & & 16 & 17,8 \\
\hline & & & & \multirow{5}{*}{$\begin{array}{l}\text { Mobbing } \\
\text { uygulayanın } \\
\text { ünvan }\end{array}$} & Arş. Gör.* & 1 & 1,1 \\
\hline & & & & & Öğr.Gör.* ${ }^{*}$ & 15 & 16,7 \\
\hline & & & & & Dr. Öğr. Üyesi* & 30 & 33,3 \\
\hline & & & & & Doç. Dr. $^{*}$ & 45 & 50 \\
\hline & & & & & $\begin{array}{l}\text { Prof. Dr. }{ }^{*} \\
\text { Diŏer (idari nersonel) }{ }^{*}\end{array}$ & $\begin{array}{r}39 \\
9\end{array}$ & $\begin{array}{r}43,3 \\
10\end{array}$ \\
\hline
\end{tabular}

*Akademisyenler birden fazla seçeneği işaretlemişlerdir. Yüzdeler sayı üzerinden değerlendirilmiştir.

Akademisyenlerin Mobbinge Maruz Kalmalarının Sebepleri ve Verdikleri Tepkiler

Akademisyenler mobbinge maruz kalmalarının kişisel nedenlerinin daha çok kıskançlık $(\% 53,3)$ ve dış görünüş (\%40) olduğunu belirtmişlerdir. Daha sonraki sebepler ise kişisel başarılar $(\% 37,8)$, siyasi görüş (\%30), girişimci ve sosyal olma $(\% 21,1)$, dini inanış (\%20) ve medeni durum (\%10)'dur. Akademisyenler mobbinge maruz kalmalarının örgütsel nedenlerinin ise daha çok sağlıklı olmayan örgüt kültürü $(\% 51,1)$, kayırmacılık $(47,8)$, ve yetersiz yöneticiler $(\% 40,1)$ olduğunu belirtmişlerdir (Tablo 2).

Akademisyenlerin \%55,6'sı uygulanan mobbing karşısında sessiz kaldıklarını belirtmiş̧lerdir. \%34,4'ü mobbing karşısında rapor/izin aldıklarını ve sabah işe gitmek istemediklerini $(\% 25,6)$ belirtirken, $\% 24,4$ 'ü işi bırakmak istediğini belirtmiştir (Tablo 2).

Tablo 2. Akademisyenlerin mobbing davranışına maruz kalma nedenleri ile verdikleri tepkilerin yüzde ve frekans dağılımı $(\mathrm{n}=90)$

\begin{tabular}{|c|c|c|c|c|c|}
\hline Değiskenler & $\mathbf{f}$ & $\%$ & Değiskenler & $\mathbf{f}$ & $\%$ \\
\hline $\begin{array}{l}\text { Mobbinge Maruz Kalmanın Kişsiel } \\
\text { Nedenleri* }\end{array}$ & & & $\begin{array}{l}\text { Mobbinge Maruz Kalmanın Örgütsel } \\
\text { Nedenleri* }^{*}\end{array}$ & & \\
\hline Kıskançlık & 48 & 53,3 & Örgüt içerisindeki iletissimsizlik & 34 & 37,8 \\
\hline Kişisel Başarılarım & 34 & 37,8 & Örgüt içindeki dayanışma eksikliği & 42 & 46,7 \\
\hline Girişimci ve Sosyal Oluşum & 19 & 21,1 & Sağlıklı olmayan örgüt kültürü & 46 & 51,1 \\
\hline Medeni durumum & 9 & 10 & Yetersiz yöneticiler & 37 & 41,1 \\
\hline Dini inançlarım & 18 & 20 & Mükemmelliyetçilik & 16 & 17,8 \\
\hline Siyasi görüşüm & 27 & 30 & Kayırmacilık & 43 & 47,8 \\
\hline D1ş görünüşüm & 36 & 40 & & & \\
\hline Cinsiyetim & 26 & 28,9 & & & \\
\hline \multicolumn{4}{|c|}{ Mobbing e karşı verilen tepkiler* } & & \\
\hline & $\mathrm{f}$ & $\%$ & & say1 & $\%$ \\
\hline Sessiz kaldım & 50 & 55,6 & Mobbing uygulayan ile yüzleștim & 22 & 24,4 \\
\hline İzin/rapor aldım & 31 & 34,4 & İşimi bırakmayı düşündüm & 22 & 24,4 \\
\hline Sabahları işe gitmek istemedim & 23 & 25,6 & Psikolojik destek aldım & 7 & 7,8 \\
\hline Aynı şekilde karşılık verdim & 10 & 11,1 & İntihar etmeyi düşündüm & 7 & 7,8 \\
\hline Ailemle paylaştım & 17 & 18,9 & Hukuki yollara başvurdum & 9 & 10 \\
\hline Yöneticilere bildirdim & 16 & 17,8 & & & \\
\hline
\end{tabular}

*Akademisyenler birden fazla seçeneği işaretlemişlerdir. Yüzdeler sayı üzerinden değerlendirilmiştir.

\section{Akademisyenlerin Mobbing Algıları ve Mesleki Tükenmislik Düzeyleri}

Akademisyenlerin algıladıkları mobbing düzeyleri puan ortalamalarının 56,76 olduğu görülmektedir. Akademisyenlerin duygusal tükenme altboyutu puan ortalamaları 17,36 ve duyarsızlaşma altboyutu puan ortalamaları 12,37 olarak belirlendi. (Tablo 3).

Tablo 3. Akademisyenlerin mobbing algıları ve tükenmişlik düzeyleri $(n=90)$

\begin{tabular}{|l|l|r|r|r|r|}
\hline & N & \multicolumn{1}{l|}{ Ort. } & \multicolumn{1}{l|}{ Ss } & \multicolumn{1}{l|}{ Min. } & \multicolumn{1}{l|}{ Max. } \\
\hline Kendini Gösterebilmeye, İletişime Yönelik Saldırılar & 90 & 13,24 & 4,90 & 5,00 & 21,00 \\
\hline Sosyal İlişkilere Yönelik Saldırılar & 90 & 8,73 & 4,87 & 4,00 & 19,00 \\
\hline
\end{tabular}




\begin{tabular}{|l|r|r|r|r|r|}
\hline İtibara Yönelik Saldırılar & 90 & 8,16 & 3,75 & 3,00 & 14,00 \\
\hline Mesleki Duruma Yönelik Saldırılar & 90 & 18,08 & 7,40 & 7,00 & 32,00 \\
\hline Kişinin Psikolojik Sağlığına Yönelik Saldırılar & 90 & 5,79 & 3,23 & 3,00 & 14,00 \\
\hline Mobbing Toplam & 90 & 56,76 & 22,42 & 23,00 & 101,00 \\
\hline Duygusal Tükenme & 90 & 17,36 & 7,58 & 6,00 & 36,00 \\
\hline Duyarsızlaşma & 90 & 12,37 & 3,26 & 4,00 & 19,00 \\
\hline Kişisel Başarılarım & 90 & 13,57 & 5,14 & 1,00 & 32,00 \\
\hline
\end{tabular}

Ss: Standart Sapma

\section{Akademisyenlerin Mobbing Algıları ve Tükenmişlik Düzeylerinin Çeşitli Değişkenlere Göre Incelenmesi}

Araştırma sonuçları incelendiğinde farklı yaş gruplarındaki kişilerin algıladıkları mobbing ve mesleki tükenmişlik düzeyleri puan ortalamalarının benzer düzeyde olduğu gözlenmiştir $(p>0,05)$. Benzer ilişkiler cinsiyet, medeni durum ve akademik unvan gruplarında da gözlenmiştir $(p>0,05)$. Yaş, cinsiyeti medeni durum, akademik unvan değişkenlerine göre akademisyenlerin algıladıkları mobbing ve tükenmişlik düzeyleri arasında istatistiksel olarak anlamlı fark bulunmamıştır (p>0,05) (Tablo 4).

Yapılan Kruskall vallis testinden elde edilen sonuçlara göre, akademisyenlerin kıdem yılına göre algıladıkları moobing düzeyleri $(\mathrm{p}=0,017)$ ile tükenmişlik $(\mathrm{p}=0,001)$ düzeyleri arasında istatistiksel olarak anlamlı fark saptanmıştır $(\mathrm{p}<0,05)$. Bu sonuçlara göre 16-20 y1l arası deneyimi olan akademisyenlerin algıladıkları mobbing düzeyi puanları ortalamaları, 21 yıl ve üzeri deneyime sahip akademisyenlerin puan ortalamalarına göre istatistiksel olarak anlamlı düzeyde yüksek bulunmuştur $(\mathrm{p}=0,023)$ (Tablo 4). Benzer ilişkiler $\mathrm{p}<0,05$ düzeyinin altında kalan diğer ikili değişkelerde de gözlenmiştir.

Tablo 4. Akademisyenlerin yaş, cinsiyet, medeni durum ve unvan değişkenlerinin algıladıkları mobbing ve tükenmişlik düzeylerine etkisi $(\mathrm{n}=90)$

\begin{tabular}{|c|c|c|c|c|c|c|c|c|c|c|}
\hline & & & Alg1lan & Mobbi & & & Tükenı & şlik & & \\
\hline \multirow[t]{6}{*}{ Yaş } & Grup & $\mathrm{n}$ & ort & ss & Tİ & $\mathrm{p}$ & ort & ss & Tİ & $\mathrm{p}$ \\
\hline & $\begin{array}{ll}29 & \text { ve } \\
\text { alt1 } & \end{array}$ & 15 & 60,47 & 19,54 & \multirow[t]{5}{*}{$\mathrm{F}=0,679$} & \multirow[t]{5}{*}{0,609} & 35,87 & 9,96 & \multirow[t]{5}{*}{$\mathrm{F}=2,192$} & \multirow[t]{5}{*}{0,077} \\
\hline & $30-39$ & 41 & 54,85 & 24,75 & & & 43,95 & 13,05 & & \\
\hline & $40-49$ & 17 & 60,82 & 18,69 & & & 45,29 & 8,87 & & \\
\hline & $50-59$ & 11 & 58,45 & 24,18 & & & 46,45 & 6,28 & & \\
\hline & $\begin{array}{l}60 \text { yaş } \\
\text { ve üzeri }\end{array}$ & 6 & 45,83 & 20,21 & & & 45,83 & 9,41 & & \\
\hline \multirow[t]{2}{*}{ Cinsiyet } & Kadın & 52 & 55,98 & 23,21 & \multirow[t]{2}{*}{$t=-0,382$} & \multirow[t]{2}{*}{0,704} & 44,56 & 13,05 & \multirow[t]{2}{*}{$\mathrm{t}=1,250$} & \multirow[t]{2}{*}{0,214} \\
\hline & Erkek & 38 & 57,82 & 21,55 & & & 41,55 & 8,18 & & \\
\hline \multirow{2}{*}{$\begin{array}{l}\text { Medeni } \\
\text { durum }\end{array}$} & Evli & 49 & 55,69 & 20,27 & \multirow[t]{2}{*}{$\mathrm{t}=-0,489$} & \multirow[t]{2}{*}{0,626} & 43,84 & 9,36 & \multirow[t]{2}{*}{$\mathrm{t}=0,501$} & \multirow[t]{2}{*}{0,618} \\
\hline & Bekar & 41 & 58,02 & 24,94 & & & 42,63 & 13,34 & & \\
\hline \multirow[t]{5}{*}{$\begin{array}{l}\text { Akademik } \\
\text { ünvan }\end{array}$} & $\begin{array}{l}\text { Arş. } \\
\text { Gör. }\end{array}$ & 19 & 51,58 & 19,12 & \multirow[t]{5}{*}{$\mathrm{KW}=3,689$} & \multirow[t]{5}{*}{0,450} & 38,32 & 10,23 & \multirow[t]{5}{*}{$\mathrm{KW}=9,400$} & \multirow[t]{5}{*}{0,051} \\
\hline & Öğr.Gör. & 30 & 57,37 & 25,18 & & & 43,67 & 7,71 & & \\
\hline & $\begin{array}{l}\text { Dr. Öğr. } \\
\text { Üyesi }\end{array}$ & 26 & 57,54 & 21,09 & & & 46,15 & 15,51 & & \\
\hline & Doç. Dr. & 7 & 67,86 & 22,25 & & & 39,43 & 9,64 & & \\
\hline & Prof. Dr. & 8 & 54,50 & 24,58 & & & 47,75 & 5,68 & & \\
\hline \multirow{5}{*}{$\begin{array}{c}\text { K1dem } \\
\text { y1l1 } \\
\text { Y1l1 }\end{array}$} & $0-5$ y1l & 28 & 52,71 & 16,39 & \multirow[t]{5}{*}{$\mathrm{KW}=12,100$} & \multirow[t]{5}{*}{0,017} & 44,11 & 14,33 & \multirow[t]{5}{*}{$\mathrm{KW}=18,204$} & \multirow[t]{5}{*}{0,001} \\
\hline & $6-10$ y1l & 23 & 67,87 & 25,98 & & & 36,30 & 8,54 & & \\
\hline & $11-15$ y1l & 16 & 51,25 & 24,23 & & & 46,06 & 8,84 & & \\
\hline & $16-20 \mathrm{y} 1 \mathrm{l}$ & 12 & 64,67 & 15,44 & & & 45,58 & 9,39 & & \\
\hline & $\begin{array}{l}21 \mathrm{y} 1 \mathrm{l} \mathrm{ve} \\
\text { üzeri }\end{array}$ & 11 & 43,18 & 21,51 & & & 49,27 & 5,88 & & \\
\hline
\end{tabular}


Tİ: Test İstatistiği, F değeri Anova, $\mathrm{t}$ değeri Student $\mathrm{t}$ testinden, KW değeri Kruskall vallis testinden elde edilmiştir. $\mathrm{P}<0,05$

\section{TARTIŞMA VE SONUÇ}

Araştırmada, bir devlet üniversitesinde çalışan akademisyenlerin algıladıkları mobbing ve tükenmişlik düzeylerinin bazı demografik özellikleri ile ilişkili olup olmadığının belirlenmesi amaçlanmıştır. Bununla birlikte, akademisyenlerin algıladıkları mobbingin kişisel ve örgütsel sebepleri ile mobbinge karşı verilen tepkiler belirlenmiştir.

Araştırma sonucunda akademisyenlerin yarısından çoğu mobbinge maruz kaldıklarını, mobbing uygulayıcılarının çoğunluğunun da yöneticilik görevi olduğunu bildirmişlerdir. Bu çalışma bulgusu benzer çalışma bulgularını desteklemektedir (Çögenli ve Asunakutlu 2016, Kaçan vd., 2016; Cemaloğlu, 2007).

Akademisyenlerin \%28,8'i kadınlar tarafından, \%33,3'ü erkekler tarafından ve \%37,7'si ise her iki cinsiyetten oluşan birkaç kişi tarafından mobbing'e maruz bırakıldıklarını belirtmişlerdir. Bu veriler doğrultusunda erkeklerin, kadınlara göre daha fazla mobbing uyguladığından ve mobbing mağdurlarının neredeyse yarısının birkaç kişiden oluşan gruplar tarafindan mobbing mağduru edildiğinden bahsedilebilir.

Akademisyenler en çok Prof. Dr. ve Doç. Dr. unvanındaki diğer akademisyenler tarafindan mobbing'e maruz bırakıldıklarını belirtmişlerdir. Akademik unvan dereceleri düştükçe mobbing uygulama oranı da düşmektedir. Yöneticilik gücünü elinde bulunduran akademisyenlerin daha fazla mobbing uyguladığından bahsetmek mümkündür. Ayrıca akademisyenler, az da olsa idari personelin de mobbing uygulayan kişiler arasında olduğunu belirtmişlerdir.

Akademisyenler en çok "Bölüm Başkanları" ve "Dekanlar veya Müdürler" tarafindan mobbing'e maruz kaldıklarını belirtmişlerdir. Hoel ve arkadaşlarının (2001) yaptığı araştırmada mobbing mağduru olduğunu belirten çalışanların \%74,7'si yöneticileri tarafindan bu olaya maruz bırakıldıklarını belirtmişlerdir (Hoel vd., 2001). Benzer şekilde Çögen ve Asunakutlu'nun (2016) çalışmasında akademisyenlere mobbing uygulayan kişilerin \%89,9'unun yöneticilik görevi olduğu belirlenmiştir. Üniversitelerde çeşitli yöneticilik görevlerinde bulunan akademisyenlerin bulundukları konumu diğer akademisyenlere karşı bir üstünlük sağlama aracı olarak gördükleri söylenebilir.

Akademisyenler daha çok kıskançlık, dış görünüş, ve kişisel olarak başarılı oldukları, için mobbing'e maruz kaldıklarını belirtmişlerdir. Siyasi görüşleri, girişimci ve sosyal olma bunu takip etmektedir.

Akademisyenler örgütsel sebepler olarak, kayırmacılı̆̆ı, yöneticilerin yeterli bilgi ve donanıma sahip olmamasını ve sağlıklı olmayan örgüt kültürünü mobbing'e maruz kalmalarında etkili olan örgütsel nedenlerin en önemlileri olarak sıralamışlardır.

Akademisyenlerin çoğu mobbing olayına karşı sessiz kaldıklarını belirtirmişlerdir. Bunu sabah işe gitmek istememe ve işi bırakmayı düşünme takip etmektedir. Mobbing olayında sessiz kalmak olayın büyüyerek devam etmesine neden olabilecek sonuçlar doğurabilmektedir. Akademisyenlerin çok az bir kısmı mobbing ile karşılaştıklarında psikolojik yardım aldıklarını ve hukuki yollara başvurduklarını belirtmişlerdir. $\mathrm{Bu}$ sonuçlar Çögen ve Asunakut'nun çalışmasını desteklemektedir (Çögen ve Asunakutlu, 2016). Eğitimli, bilgili ve entelektüel diye nitelendirebileceğimiz meslek mensuplarının mobbing gibi kesinlikle hukuki destek alınmasının gerektiği bir durumda bu tercihte bulunmamalarının önemli bir etken olduğu düşünülmektedir. Bunun en büyük nedenlerinden birinin mobbing olayını ispat edememe endişesi içinde olmalarıdır.

Akademisyenlerin algıladıkları mobbing ve tükenmişlik düzeylerinin çeşitli demografik değişkenlere göre farklılık gösterip göstermediği incelendiğinde; bu kapsamda gerçekleştirilen araştırmanın bulgularına göre; akademisyenlerin algıladıkları mobbing ve tükenmişlik düzeyleri yaş, cinsiyet, medeni durum, ve akademik ünvana göre anlamlı bir farklılık göstermezken; akademisyenlerin kıdem yılına göre; mobbing ve tükenmişlik düzeylerinin farklılaştığı saptanmıştır. Kıdem yılı 21 yıl ve üstündeki akademik personelin algıladıkları mobbing düzeyinin düştüğü, tükenmişlik düzeyinin arttığı 
görülmüştür. Bununla birlikte akademisyenlerde mobbing ile tükenmişlik arasındaki ilişkiyi araştıran başka çalışmalara ihtiyaç vardır.

Türkiye'deki bir devlet üniversitesinde görev yapan sınırlı sayıda akademik personel üzerinden gerçekleştirilen bu araştırma akademisyenler üzerinde genel bir mobbing algı haritası ortaya koymaktadır. Bununla birlikte bu ve benzeri çalışmaların tekrarlanarak gelecekte mevut durumu tespit edici, mobbing miktarında görülen değişimin saptanmasına, mobbingi önlemeye yönelik uygulamaların etki düzeyinin belirlenmesine dönük yeni araştırmaların yapılması önerilebilir. Bu konu ile ilgili çeşitli araştırmalar yapılmalı, çeşitli çözüm önerileri getirilmeli ve hatta mobbing'e maruz kalmış akademisyenler tespit edilerek rehabilite edildikten sonra tekrar bilimsel çalışmalarını devam ettirebilmelerine imkan tanınmalıdır.

$\mathrm{Bu}$ çalışma ile bazı fikirler edinmekle birlikte daha kapsamlı çalışmaların yapılmasına ihtiyaç bulunmaktadır. Daha geniş örnek guruplarında ve farklı üniversite örneklem gruplarında benzer çalışmaların yapılması önerilebilir. Bununla birlikte ülkemizde akademik personelin algıladıkları mobbingin tükenmişlik düzeyine etkisini araştıran az sayıda çalışma olduğundan yola çıkılarak, bu konu üzerinde çalışmalar yapılabilir.

\section{Araştırmanın Sınırlılıkları}

Araştırmanın Bartın Üniversitesi'nin öğretim elemanları ile sınırlı olması ve sonuçların diğer üniversitelerde çalışan öğretim elemanlarına genellenememesi, araştırmada kullanılan kişisel bilgi formundan elde edilen verilerle, Akademisyenlere Yönelik Mobbing Ölçeği (AYMÖ), ve Maslach Tükenmişlik Ölçeği (MTÖ)'elde edilen verilerle sınırlı olması bu araştırmanın sınırlılıklarını oluşturmaktadır.

\section{KAYNAKÇA}

Brodsky, C. M. (1976). The Harassed Worker. Toronto- Lexington: Lexington Books.

Cemaloğlu, N. (2007). The exposure of primary school teachers to bullying: an analysis of various variables. Social Behavior and Personality, 35(6), 789-802.

Cooper, C., Hoel, H. and Faragher, B. (2004). Bullying is detrimental to health, but all bullying behaviours are not necessarily equally damaging. British Journal of Guidance \& Counselling, 32(3), 367-387.

Çam, O. (1998). Tükenmişlik nedir? Ege Üniversitesi Hemşirelik Yüksek Okulu Dergisi, 9(1), 51-53.

Çivilidağ, A. (2011). Üniversitelerdeki öğretim elemanlarının psikolojik taciz (mobbing), iş doyumu ve algılanan sosyal destek düzeyleri. Yayımlanmamış doktora tezi, Selçuk Üniversitesi, Konya.

Çögenli, M. Z. (2010). Üniversitelerde psikolojik şiddet (mobbing) maruziyeti ve akademik personel üzerine bir uygulama. Yayınlanmamış yüksek lisans tezi, Atatürk Üniversitesi, Sosyal Bilimler Enstitüsü, Erzurum.

Çögenli, M. Z., Asunakutlu, T. (2014). Akademisyenlere yönelik mobbing ölçeği geçerlik ve güvenirlik çalışması. Uşak Üniversitesi Sosyal Bilimler Dergisi, 7(2), 92-105.

Çögenli, M. Z., Asunakutlu, T. (2016). Akademide mobbing: adım üniversiteleri örneği. Erzincan Üniversitesi Sosyal Bilimler Enstitüsü Dergisi, 9(1), 17-32

Deniz, D. (2012). Mobbing (işyerinde yıldırma). İstanbul: Fam Yayınları.

Ergin, C. (1992). Doktor ve hemşirelerde tükenmişlik ve maslach tükenmişlik ölçeği'nin uyarlanması. Bayraktar. (R. ve Dağ, İ. ed.). 7. Ulusal Psikoloji Kongresi Bilimsel Çalışmaları, Ankara: Türk Psikologlar Derneği Yayınları, 143-154.

Eroğlu, F. (1996). Davranış bilimleri. 1. Baskı. İstanbul: Sistem Yayıncılık. 
Güven, A., Kaplan, Ç., Acungil, Y. (2018). Türkiye'de özel ve kamu üniversitelerinde çalışan akademisyenlerin mobbing algısı. Akademik Araştırmalar ve Çalışmalar Dergisi, 10(18), 43-58.

Hoel, H., Cooper, C. L., Faragher, B. (2001). The experience of bullying in Great Britain: The impact of organizational status. European Journal of Work and Organizational Psychology, 10(4), 443-465.

Karatuna, I., Gök, S. (2012). Yükseköğretimde psikolojik taciz konulu araştırmalar üzerine bir inceleme. Uluslararast İsyerinde Psikolojik Taciz Kongresi, İzmir: Bilinder, 41-60.

Kayac1, Ü. (2014). Akademik ortamlarda psikolojik şiddet (mobbing) ve y1lmazlık. Journal of Turkish Educational Sciences, 12(2),7-78.

Kırel, Ç. (2007). Örgütlerde mobbing yönetiminde destekleyici ve risk azaltıcı öneriler. Anadolu Üniversitesi Sosyal Bilimler Dergisi, 7(2), 317-334.

Laleoğlu, A., Özmete, E. (2013). Mobbing ölçeği: Geçerlik ve güvenirlik çalışması. Sosyal Politika Çalışmaları, 31, 9-31.

Leymann, H. (1990). Important note in preface to heinz leymann, mobbing and psychological terror at workplaces. Violence and Victims, 5, 119-126.

Matthiesen, S. B., Einarsen, S. (2010). Bullying in the workplace: Definition, prevalence, antecedents and consequences. International Journey of Organization Theory and Behavior, 13(2), 198236.

Maslach, C., Jackson, S.E. (1981). The measurement of experienced burnout. Journal of Occupational Behaviour, 2, 99-113.

Maslach, C., Schaufeli, W.B., Leiter, M.P. (2001). Job burnout. Annual Review Psychology, 52, 397422.

Maslach, C. (2003). Job burnout: New directions in research and intervention. Current Directions in Psychological Science, 12(5), 189-192.

Öztürk, M., Şahbudak, E. (2017). İş yerinde psikolojik taciz (mobbing) ve iş doyumu: cumhuriyet üniversitesindeki araştırma görevlileri üzerine bir çalışma. Sosyoloji Araştırmaları Dergisi, 20(2), 200-228.

Sarı, E. G. (2018). Akademisyenlerin mobbing algılarının örgütsel yabancılaşma düzeyleri ile ilişkisi (Munzur üniversitesi örneği). Yayımlanmamış yüksek lisans tezi, Burdur Mehmet Akif Ersoy Üniversitesi, Eğitim Bilimleri Enstitüsü, Burdur.

Sart, G., Sezgin, F. H., Demir, N. (2018). Mobbingin mesleki tükenmişlik algısı üzerine etkileri: kadın akademisyenler örneği. Beykoz Akademi Dergisi, 6(1), 118-135.

Serinkaya, C., Bardakcı, A. (2009). Pamukkale Üniversitesi'ndeki akademik personelin iş tatminleri ve tükenmişlik düzeylerine ilişkin bir araştırma. Sosyal Bilimler Dergisi, 21, 116-132.

Softa, H. K., Bükecik, E., Colak, A. ve Göçer, D. (2016). Akademisyenlerin mobbing durumlarının incelenmesi. Ege Üniversitesi Hemşirelik Fakültesi Dergisi, 32(1), 34-47.

Şahbudak, E. ve Öztürk, M. (2015). İş yerinde psikolojik taciz: cumhuriyet üniversitesinde çalışan akademisyenler üzerine bir çalıșma. Akademik Sosyal Araştırmalar Dergisi, 3(15), 146-160.

Şenerkal, R., Çorbacıoğlu, S. (2015). Akademik personelin algıladığı psikolojik taciz davranışları ile iş performansı, psikolojik ve fizyolojik sağlık ilişkisi üzerine bir araştırma. İktisadi ve İdari Bilimler Fakültesi Dergisi, 17(1), 107-135.

Tınaz, P. (2006). Isşyerinde psikolojik taciz (Mobbing). İstanbul: Beta Basım A.Ş. 
Türeli, N. Ş., Dolmacı, N. (2013). İş yaşamında kadın çalışana yönelik ayrımcı bakış açısı ve mobbing üzerine ampirik bir çalışma. Muğla Sıtkı Koçman Üniversitesi İktisadi ve İdari Bilimler Fakültesi Ekonomi ve Yönetim Araştırmaları Dergisi, 2(2), 93-103.

YÖK, (2007). Türkiye’nin Yükseköğretim Stratejisi. Ankara: T.C. Yükseköğretim Kurulu.

Varhama, Lasse M., Björkqvist, Kaj (2004). Conflicts, workplace bullying and burnout problems among municipal employees. Psychological Reports, 94(3), 1116- 1124.

Yeloğlu, H. O., Karahan, G. (2016). Mobbing problemi'nin akademik çalışanlar ve sosyal hayatları üzerindeki etkileri: sözleşme sorunu. Savunma Bilimleri Dergisi, 15(2), 47-71. 